\title{
EKONOMI ISLAM DAN KAPITALISME (Merunut Benih Kapitalisme dalam Ekonomi Islam)
}

\author{
Choirul Huda ${ }^{1}$
}

\begin{abstract}
A discussion of the modern economic system, usually refers to two major systems, namely capitalism based on the capital markets (capital) and guided socialism which tried to solve problems of production, consumption and distribution through the chain of command. In addition to these two major systems, also known as the Islamic economic system, which refers to the economic practice of the Prophet Muhammad, peace be upon him. Islamic economic system is an alternative to the fundamental problems of the two major systems that already exist. However, when referring to the conditions of the birth of Islam in the midst of Arab society steeped in culture trade, alleged the influence of the capitalist culture of the economic system of Islam, so Islam is perceived closer to capitalism than socialism. Through the study of literary conclusion that Islam and capitalists are the two things affect each other. Sociologically, Islam is present in a capitalist society that both have an attachment. Capitalism, especially trade capitalism existed before Islam came. Before the birth of Islam, Mecca has become the center of international trade and finance. The Prophet Muhammad himself was a merchant before it became a prophet. Thus, capitalism is an ideology or a system that comes from the outside and into the schools of economic thought incoming and economic influence of Islam, although Islam also influence and correct the economic life or Capitalism applicable. Therefore Islam and capitalism are two forces that interact and influence.
\end{abstract}

Keywords: Economic System, Capitalist, Sosisalis, Islam

\section{Pendahuluan}

Dalam sejarah peradaban manusia, ada beberapa bentuk sistem ekonomi yang pernah ditemukan sebagai solusi atas persoalan ekonomi umat manusia. Bentuk paling primitif adalah despotisme, dimana ekonomi diatur oleh sebuah otoritas tunggal, baik seorang atau sekelompok orang yang menjadi pemimpin. Sistem despotik bukannya tidak berhasil. Peradabanperadaban besar di masa lalu dibangun di atas sistem ini. Problem dengan

\footnotetext{
${ }^{1}$ Dosen Fakultas Ekonomi dan Bisnis Islam, UIN Walisongo Semarang
}

Volume VII/Edisi 1/Mei 2016 
Ekonomi Islam dan Kapitalisme...

despostisme adalah ia tidak berkelanjutan. Sistem ini tidak mampu mengatasi problem yang makin kompleks yang dihadapi umat manusia. Karena itu, sistem ini kemudian punah. Sistem ini setidaknya hanya eksis di tingkat masyarakat yang terbatas.

Ketika berbicara soal sistem ekonomi modern, kita biasanya merujuk pada dua sistem besar: kapitalisme pasar dan sosialisme terpimpin. Kapitalisme adalah sistem yang didasarkan atas pertukaran yang sukarela (voluntary exchanges) di dalam pasar yang bebas. Sebaliknya, sosialisme mencoba mengatasi problem produksi, konsumsi dan distribusi melalui perencanaan atau komando. Hal yang perlu digarisbawahi adalah fakta bahwa ada dua sistem besar dalam ekonomi modern tidak berarti adanya dikotomi atau bipolarisasi.

Saat ini tidak ada yang bisa membantah kedigdayaan rezim kapitalisme mendominasi peradaban dunia global. Berakhirnya Perang Dingin menyusul ambruknya komunisme-sosialisme Uni Soviet beserta negara-negara satelitnya sering diinterpretasikan sebagai kemenangan kapitalisme. Hampir dalam setiap sektor kehidupan, logika dan budaya kapitalisme hadir menggerakkan aktivitas. Kritik-kritik yang ditujukan terhadap kapitalisme justru bermuara kepada terkooptasinya kritik-kritik tersebut untuk lebih mengukuhkan kapitalisme.

Islam, sebagai sebuah agama langit yang komplit, mengatur segala sendi kehidupan umat manusia, termasuk ekonomi. Ekonomi Islam, sebenarnya telah lahir sejak Muhammad saw memulai kariernya sebagai pedagang. Meskipun institusi Islam saat itu belum muncul, namun Muhammad sudah mempraktikkan sistem perdagangan yang di kemudian hari diakomodir dalam Islam. Tentu ekonomi Islam memiliki ciri khas yang membedakannya dengan yang lain, termasuk dengan kapitalisme maupun sosialisme.

Hubungannya dengan kapitalisme, ada beberapa pertanyaan yang menggelitik. Pertama, apakah ekonomi Islam mengakomodasi sistem ekonomi kapitalis dalam penerapannya? Kedua, adakah keterkaitan antara ekonomi Islam dengan kapitalisme yang akhirnya menjadi penghubung antar keduanya untuk sama-sama menjadi sistem alternatif yang mendunia?Artikel berikut mencoba menjawab dua pertanyaan tersebut. 


\section{Pengertian Kapitalisme}

Kapitalisme berasal dari asal kata capital yaitu berarti modal, yang diartikan sebagai alat produksi semisal tanah dan uang. Sedangkan kata isme berarti paham atau ajaran. Kapitalisme merupakan sitem ekonomi politik yang cenderung ke arah pengumpulan kekayaan secara individu tanpa gangguan kerajaan. Dengan kata lain kapitalisme adalah suatu paham ataupun ajaran mengenai segala sesuatu yang berhubungan dengan modal atau uang.

Dalam dunia ekonomi peran modal sangatlah besar, bahkan pemilik modal bisa menguasai pasar serta menentukan harga dalam rangka mengeruk keuntungan yang besar. Industrialisasi bisa berjalan dengan baik kalau melalui kapitalisme. Fernand Braudel pernah menyatakan bahwa "kaum kapitalis merupakan spekulator dan pemegang monopoli yang berada dalam posisi untuk memperoleh keuntungan besar tanpa menanggung banyak risiko"2

Menurut Ayn Rand, kapitalisme adalah a social system based on the recognition of individual rights, including property rights, in which all property is privately owned (suatu sistem sosial yang berbasiskan pada pengakuan atas hak-hak individu, termasuk hak milik di mana semua pemilikan adalah milik privat). ${ }^{3}$

Kapitalisme, sebagaimana yang diperkenalkan oleh Karl Marx (lahir dari keluarga progresif Yahudi. Ayahnya bernama Herschel keturunan para Rabisekitar abad 19 yang sering dijuluki sebagai bapak dari komunisme yang berasal dari kaum terpelajar dan politikus), ${ }^{4}$ adalah suatu sistem produksi yang didasarkan pada hubungan antara kapital dengan tenaga kerja. Pemilik modal (kapital) memiliki hak penuh terhadap apa yang dimiliki. ${ }^{5}$ Maka dalam kapitalisme ada individual ownership, market economy ${ }^{6}$, competition, and profit. ${ }^{7}$

Senada dengan itu, kapitalis ialah hubungan-hubungan di antara para pemilik pribadi atas alat-alat produksi yang bersifat non-pribadi (tanah,

\footnotetext{
${ }^{2}$ Yoshihara Kunio, Kapitalisme Semu Asia Tenggara, Jakarta: LP3ES, 1990, hlm. 3

3 Ayn Rand, Capitalism: The Unknown Ideal, A Signet Book, New York: 1970. 190.

${ }^{4}$ Jonathan H. Turner, The Emergence of sociological theory, Illinois: The Dorsey Press, 1981, hlm. 165-

${ }^{5}$ Kepemilikan pribadi misalnya alat-alat produksi, tanah, perusahaan, dan sumber daya alam.

${ }^{6}$ Sistem pasar adalah sistem yang dipakai sebagai dasar pertukaran barang dan jasa, serta tenaga kerja menjadi komoditi yang dapat diperjualbelikan di pasar dalam kapitalisme.

${ }^{7}$ W. Ebenstein, Isme-Isme Dewasa Ini, (terj), Jakarta: Erlangga, 1980, hlm. 148-151.
} 
Ekonomi Islam dan Kapitalisme...

tambang, instalasi industri dan sebagainya, yang secara keseluruhan disebut modal atau kapital) dengan para pekerja yang biar pun bebas namun tak punya modal, yang menjual jasa tenaga kerjanya kepada para majikan. ${ }^{8}$

Pengertian lain menyebutkan, kapitalisme, sesuai asal katanya kapital yang berarti modal, ialah sistem perekonomian yang menganggap modal sebagai penggerak perekonomian. Kapitalisme mengakui kekuasaan kaum pemodal (kapitalis) sebagai motor perekonomian yang menanamkan modalnya dengan mengambil resiko kerugian atas usahanya. Pasar yang dikehendaki sebagai alokator interaksi supply dan demand yang sempurna dan efisien adalah mekanisme pasar bebas. Maksudnya, biarkan saja perekonomian berjalan dengan wajar tanpa campur tangan pemerintah, sebab nanti akan ada tangantangan tak terlihat (invisible hands) yang akan membawa perekonomian tersebut ke arah keseimbangan. Dalam hal ini, kapitalisme adalah sebuah sistem di mana negara memberikan kebebasan bagi warganya untuk mengelola semua sumber daya dan kekayaan yang dimilikinya, namun tetap tidak boleh terjadi praktik monopoli di pasar. Sebab, pandangan semua ekonom sadar, termasuk para pemikir kapitalis, bahwa monopoli adalah penyakit yang akan merusak dan menghancurkan sebuah sistem perekonomian. Maka tidak heran, Adam Smith, pelopor sistem ini, menganjurkan peran negara seminimal mungkin dan mengusahakan seluas-luasnya kebebasan bagi para pelaku ekonomi yang mengandalkan self-interest-nya. Inilah konsep laissez faire-laissez passer ala kaum fisiokrat yang berawal dari pendapat Francis Quesnay.

Adalah sebuah keniscayaan, seandainya fenomena ketimpangan pendapatan memang terjadi dalam sistem kapitalisme karena persaingan yang terjadi dalam masalah alokasi sumber daya. Kemiskinan sebagai konsekuensi dari ketimpangan pendapatan, merupakan gejala alamiah (sunnatulläh) yang tidak hanya terjadi dalam sistem kapitalisme, tetapi lebih disebabkan rendahnya faktor produktivitas dan kemajuan masyarakat. Inilah yang dilawan oleh kapitalisme melalui konsep spesialisasi pekerjaan (division of labour).

${ }^{8}$ Dudley Dillard, Kapitalisme Dulu dan Sekarang, terj. M. Dawam Rahardjo, Jakarta: LP3ES, 1987, hlm. 15 . 


\section{Sejarah Kapitalisme}

Kapitalisme muncul di Eropa pada abad ke-16. Secara sosiologis paham kapitalisme berawal dari perjuangan terhadap kaum feodal. Kapitalisme di Eropa muncul dari pemikiran kaum ilmiah yang pada awalnya berfikir untuk mensejahterakan kaum buruh. Max Weber dalam karyanya The Protestan Ethic of Spirit Capitalism, mengungkapkan bahwa kemunculan kapitalisme erat sekali dengan semangat religius terutama kaum protestan. Pendapat Weber ini didukung Marthin Luther King yang mengatakan bahwa lewat perbuatan dan karya yang lebih baik manusia dapat menyelamatkan diri dari kutukan abadi. Tokoh lain yang mendukung adalah Benjamin Franklin dengan mottonya yang sangat terkenal yaitu "Time Is Money", bahwa manusia hidup untuk bekerja keras dan memupuk kekayaan.

Menurut Dudley Dillard, Sejarah kapitalisme melewati tiga fase, yaitu kapitalisme awal, kapitalisme klasik, dan kapitalisme lanjut. ${ }^{9}$

Kapitalisme Awal (1500-1750)

Kapitalisme awal dimulai dengan lahirnya institusi pasar (market) pada abad ke-16 dan dilanjutkan dengan perkembangan perdagangan jarak jauh antar pusat-pusat kapitalisme dunia. Pada akhir abad pertengahan (abad 16 sampai 18), Industri di Inggris sedang terkonsentrasi pada industri sandang. Industri sandang di Inggris menjadi industri sandang terbesar di Eropa. Meskipun banyak masalah yang di hadapi akan tetapi industri sandang di Ingris menjadi industri yang sangat pesat. Industri sandang inilah yang menjadi pelopor lahirnya kapitalisme di Eropa sebagai suatu sistem sosial dan ekonomi. Kemudian industri ini berlanjut pada usaha perkapalan, pergudangan, bahanbahan mentah, barang-barang jadi dan variasi bentuk kekayaan yang lain. Dan kemudian berubah menjadi perluasan kapasitas produksi.

Dari beberapa kejadian dan juga faktor lingkungan historis mempengaruhi pembentukan modal di Eropa Barat pada awal terbentuknya kapitalisme antara lain: 1) dukungan agama bagi kerja keras dan sikap hemat; 2) pengaruh logam-logam mulia dari dunia baru terhadap perkembangan relatif pendapatan atas upah, laba, dan sewa; 3) peranan negara dalam membantu dan

9 RH. Tawney, Religion and The Rise of Capitalism, 1922. 
secara langsung melakukan pembentukan modal dalam bentuk benda-benda modal aneka guna.

Etika ekonomi yang diajarkan katolisme abad pertengahan menciptakan banyak hambatan bagi perkembangan kapitalis dan ideologi kapitalis. ${ }^{10} \mathrm{Di}$ perkotaan, para pedagang kapitalis menjual barang-barang produksi mereka selama mereka melakukan satu perjalanan dari satu tempat ke tempat lainnya. Awalnya mereka menjual barang pada teman sesama pedagang seperjalanan, lalu berkembang menjadi perdagangan umum. Sementara di wilayah pedesaan saat itu masih cenderung feodalistik.

Dalam hal ini Russel mengemukakan adanya tiga faktor yang menghambat kapitalisme di pedesaan dan berbagai wilayah lain. Kendala itu adalah :

a. Tanah yang ada hanya digunakan untuk bercocok tanam, sehingga hasil produksinya sangat terbatas. Russel mengusulkan untuk mengubah tanah menjadi sesuatu yang lebih menguntungkan (profitable). Atau dengan pengertian lain tanah bisa diperjual belikan seperti barang lainnya.

b. Para petani atau buruh tani yang masih terikat pada sistem ekonomi subsistensi. Komentar Russel untuk hal ini adalah mereka siap untuk dipekerjakan dengan upah tertentu.

c. Hasil produksi yang diperoleh petani saat itu hanya sekedar digunakan untuk mencukupi kebutuhan pribadi. Menurut Russel, produksi hasil petani harus ditawarkan ke pasar dan siap dikonsumsi oleh publik.

Evolusi harga di dunia baru membawa dampak mendalam pada kapitalisme Eropa, pada kelas-kelas ekonomis dan distribusi pendapatan di Mexico, Peru dan Bolivia. Tingginya harga dan rendahnya upah mengakibatkan inflasi keuntungan, yang pada akhirnya menyumbang pada membesarnya akumulasi modal.

Kapitalisme Klasik (1750 - 1914)

Fase di mana kapitalisme mulai masuk dan merupakan pergeseran dari perdagangan publik ke bidang industri. Fase ini ditandai dengan adanya Revolusi Industri di Inggris. Di Inggris mulai banyak diciptakan mesin-mesin

10 Dillard, Kapitalisme ..., hlm. 17. 
besar yang sangat berguna untuk menunjang industri. Revolusi Industri dapat didefinisikan sebagai periode peralihan dari dominasi modal perdagangan atas modal industri ke dominasi modal industri atas modal perdagangan. ${ }^{11}$

Kapitalisme mulai menjadi penggerak kuat bagi perubahan teknologi karena akumulasi modal memungkinkan penggunaan penemuan baru yang tak mungkin dilakukan oleh masyarakat miskin. Di fase inilah mulai dikenal tokoh yang disebut "bapak kapitalisme" yaitu Adam Smith. Adam Smith bersama dengan bukunya yang sangat tekenal yaitu The Wealth Of Nations (1776). Buku ini mencerminkan ideologi kapitalisme klasik. Salah satu poin ajarannya "laissez faire"12 dengan invisible hand-nya (mekanisme pasar). Kebijaksanaan laissez faire mencakup pula perdagangan bebas, keuangan yang kuat, anggaran belanja seimbang, bantuan kemiskinan minimum. Tak ada satu konsepsi baru pun tentang masyarakat yang dapat menandingi peradaban kapitalisme.

\section{Kapitalisme Lanjut (1914 - Sekarang)}

Peristiwa besar yang menandai fase ini adalah terjadinya Perang Dunia I. Kapitalisme lanjut sebagai peristiwa penting ini ditandai paling tidak oleh tiga momentum. Pertama, pergeseran dominasi modal dari Eropa ke Amerika. Kedua, bangkitnya kesadaran bangsa-bangsa di Asia dan Afrika sebagai akses dari kapitalisme klasik, yang kemudian memanifestasikan kesadaran itu dengan perlawanan. Ketiga, revolusi Bolshevik Rusia yang berhasrat meluluhlantakkan institusi fundamental kapitalisme yang berupa pemilikan secara individu atas penguasaan sarana produksi, struktur kelas sosial, bentuk pemerintahan dan kemapanan agama. Dari sana muncul ideologi tandingan yaitu komunisme.

Ada tiga hal yang menjadi pola sifat dan watak dasar kapitalisme. Tiga hal tersebut yang melandasi adanya penindasan yang terjadi dari sejak munculnya kapitalisme sampai praktek kapitalisme yang terjadi detik ini. Tiga hal tersebut adalah:

1. Eksploitasi

Ini berarti pengerukan secara besar-besaran dan habis-habisan terhadap sumberdaya alam maupun sumberdaya manusia, seperti yang terjadi pada

\footnotetext{
${ }^{11} \mathrm{Ibid}, \mathrm{hlm} .22$.

${ }^{12}$ Istilah "Laissez Faire" berasal dari bahasa Perancis laissez faire la nature (let nature take its course); dapat diartikan sebagai sikap pembiaran kebebasan semaunya tanpa pengaturan dan kontrol.
} 
Ekonomi Islam dan Kapitalisme...

jaman penjajahan, bahkan sampai sekarang meskipun dalam bentuk yang tidak sama. Kaum kapitalis akan terus melakukan perampokan besarbesaran terhadap kekayaan alam kita dan terus mengeksploitasi para buruh demi kepentingan dan keuntungan pribadi.

2. Akumulasi

Secara harfiah akumulasi berarti penumpukan. Sifat inilah yang mendasari kenapa kapitalis tidak pernah puas dengan dengan apa yang telah diraih. Misalnya, kalau pertama modal yang dipunyai adalah Rp. 1 juta maka si kapitalis akan berusaha agar bisa melipatgandakan kekayaannya menjadi Rp. 2 juta dan seterusnya. Sehingga kaum kapitalis selalu menggunakan segala cara agar kekayaan mereka berkembang dan bertambah.

3. Ekspansi

Ini berarti pelebaran sayap atau perluasan wilayah pasar, seperti yang pada kapitalisme fase awal. Yaitu dari perdagangan sandang diperluas pada usaha perkapalan, pergudangan, barang-barang mentah dan selanjutnya barang-barang jadi. Dan yang terjadi sekarang adalah kaum kolonialis melakukan ekspansi ke seluruh penjuru dunia melalui modal dan pendirian pabrik-pabrik besar yang nota bene adalah pabrik lisensi, yang semakin dimuluskan dengan jalan globalisasi.

Kapitalisme yang lahir dari pemikiran masyarakat feodal kini telah menjadi senjata ampuh negara maju untuk memajukan perekonomian mereka. Sementara itu kapitalisme juga telah membunuh perekonomian negara berkembang atau negara-negara miskin. Konsep kapitalisme yang sudah mendunia memang tidak bisa dihindari oleh negara-negara maju dan negaranegara dunia ketiga. Tanpa disadari kapitalisme telah menjadi sebuah ancaman besar bagi masyarakat negara-negara berkembang. Kapitalisme telah menjadi neo-Imperialisme yaitu penjajahan dengan konsep baru yang lebih modern.

\section{Kapitalisme dan Liberalisme}

Di antara fondasi ilmu ekonomi adalah perlindungan hak milik pribadi (property right) yang merupakan juga fondasi atas prinsip kebebasan (liberty) yang dikemukakan oleh John Locke. Ia mengklaim bahwa civil society dibentuk untuk perlindungan atas hak milik pribadi. Prinsip kebebasan tersebut melahirkan 
juga doktrin kebebasan berusaha (free enterprise), kebebasan bekerja yang melahirkan pekerja bebas (free labour). Secara keseluruhan prinsip-prinsip itu membentuk doktrin ekonomi pasar bebas (free market economy). Sementara itu kebebasan berusaha tidak akan terjadi jika tidak ada insentif berupa kebebasan mengakumulasi kekayaan atau modal.

Semua prinsip kebebasan itu digandengkan menjadi benang merah dalam aliran pemikiran ekonomi liberal. Dengan demikian maka kapitalisme adalah perwujudan dari prinsip-prinsip liberalisme ekonomi atau ekonomi liberal. Prinsip-prinsip liberalisme itu ternyata memang membuktikan diri mampu mendorong perkembangan ekonomi dan sistem Kapitalisme.

Liberalisme muncul dari akibat meledaknya revolusi industri di Eropa yaitu perubahan sistem feodal menjadi liberal. Liberalisme di Eropa merubah seluruh aspek kehidupan masyarakat pada zaman itu. Liberalisme mulai masuk pada sendi-sendi kehidupan masyarakat Eropa seperti politik, ekonomi dan sosial budaya.

Kaum kapitalis memandang kebebasan adalah suatu kebutuhan bagi individu untuk menciptakan keserasian antara dirinya dan masyarakat. Sebab kebebasan itu adalah suatu kekuatan pendorong bagi produksi karenaia benarbenar menjadi hak manusia yang menggambarkan kehormatan kemanusiaan.

Dalam perkembangannya kapitalisme menjadi sangat berpengaruh kepada seluruh aspek global kemasyarakatan. Sistem kapitalisme membentuk sistem sekulerisme, yang menghalangi agama terlibat dalam kebijakan ekonomi. Kapitalisme juga mengenal liberalisasi perdagangan dalam bentuk pasar bebas. Perdagangan bebas yang dilakukan berdasarkan sistem kapitalisme merupakan bentuk baru dari kapitalisme global. Selain itu pengaruh dari kapitalisme global adalah munculnya liberalisme di bidang perekonomian.

Pendapat Adam Smith yang paling penting ialah tentang ketergantungan peningkatan perekonomian, kemajuan, dan kemakmuran kepada kebebasan ekonomi yang tercermin pada kebebasan individu yang secara bebas memilih pekerjaannya sesuai dengan kemampuannya sehingga dapat mewujudkan penghasilan yang dapat memenuhi kebutuhan dirinya. Kebebasan berdagang di mana produktivitas peredaran produksi dan distribusinya berlangsung dalam iklim persaingan bebas. 
Ekonomi Islam dan Kapitalisme...

\section{Prinsip Dasar Kapitalisme}

Bapak kapitalisme, Adam Smith mengemukakan 5 teori dasar dari kapitalisme:

1. Pengakuan hak milik pribadi tanpa batas-batas tertentu.

2. Pengakuan hak pribadi untuk melakukan kegiatan ekonomi demi meningkatkan status sosial ekonomi.

3. Pengakuan adanya motivasi ekonomi dalam bentuk semangat meraih keuntungan semaksimal mungkin.

4. Kebebasan melakukan kompetisi.

5. Mengakui hukum ekonomi pasar bebas/mekanisme pasar.

Tiga Asumsi Kapitalisme Menurut Ayn Rand

Ayn Rand dalam Capitalism (1970) menyebutkan tiga asumsi dasar kapitalisme, yaitu: (a) kebebasan individu, (b) kepentingan diri (selfishness), dan (c) pasar bebas. Menurut Rand, kebebasan individu merupakan tiang pokok kapitalisme, karena dengan pengakuan hak alami tersebut individu bebas berpikir, berkarya dan berproduksi untuk keberlangsungan hidupnya. Pada gilirannya, pengakuan institusi hak individu memungkinkan individu untuk memenuhi kepentingan dirinya. Menurut Rand, manusia hidup pertama-tama untuk dirinya sendiri, bukan untuk kesejahteraan orang lain. Rand menolak keras kolektivisme, altruisme, mistisisme. Konsep dasar bebas Rand merupakan aplikasi sosial dan pandangan epistemologisnya yang natural mekanistik. Terpengaruh oleh gagasan the invisible hand dari Smith, pasar bebas dilihat oleh Rand sebagai proses yang senantiasa berkembang dan selalu menuntut yang terbaik atau paling rasional. Smith pernah berkata: ...free marker forces is allowed to balance equitably the distribution of wealth. ${ }^{13}$

\section{Akumulasi Kapital}

Heilbroner (1991) menelaah secara mendalam pengertian hakiki dari kapital. Apa yang dimaksud dengan kapital sehingga dapat menjelaskan formasi sosial tempat kita hidup sekarang adalah kapitalisme? Heilbroner menolak memperlakukan kapital hanya dalam kategori hal-hal yang material

13 Robert. E. Lerner, Western Civilization, Volume 2, W.W. Norton \& Company, Ney YorkLondon: 1988. 
berupa barang atau uang. Menurutnya, jika kapital hanya berupa barang-barang produksi atau uang yang diperlukan guna membeli material dan kerja, maka kapital akan sama tuanya dengan peradaban.

Menurut Heilbroner, kapital adalah faktor yang menggerakkan suatu proses transformasi berlanjut atas kapital-sebagai-uang menjadi kapitalsebagai-komoditi, diikuti oleh suatu transformasi dari kapital-sebagai-komoditi menjadi kapital-sebagai uang yang bertambah. Inilah rumusan M-C-M yang diperkenalkan Marx.

Proses yang berulang dan ekspansif ini memang diarahkan untuk membuat barang-barang dan jasa-jasa dengan pengorganisasian niaga dan produksi. Eksistensi fisik benda dan jasa itu merupakan suatu rintangan yang harus diatasi dengan mengubah komoditi menjadi uang kembali. Bahkan kalau hal itu terjadi, bila sudah terjual, maka uang itu pada gilirannya tidak dianggap sebagai produk akhir dari pencarian tetapi hanya sebagai suatu tahap dalam lingkaran yang tak berakhir.

Karena itu, menurut Heilbroner, kapital bukanlah suatu benda material melainkan suatu proses yang memakai benda-benda material sebagai tahaptahap dalam eksistensi dinamiknya yang berkelanjutan. Kapital adalah suatu proses sosial, bukan proses fisik. Kapital memang mengambil bentuk fisik, tetapi maknanya hanya bisa dipahami jika kita memandang bahwa bendabenda material ini mewujudkan dan menyimbolkan suatu totalitas yang meluas.

Rumusan M-C-M (Money-Commodity-Money) yang diskemakan Marx atas metamorfosis yang berulang dan meluas yang dijalani kapital merupakan penemuan Marx terhadap esensi kapitalisme, yaitu akumulasi modal. Dalam pertukaran M-C-M tersebut uang bukan lagi alat tukar, tetapi sebagai komoditas itu sendiri dan menjadi tujuan pertukaran.

Dorongan Untuk Mengakumulasi Kapital (Heilbroner)

Analisis kapital sebagai suatu proses ekspansif seperti yang diuraikan di muka, ditelaah lebih dalam lagi oleh Heilbroner melalui pendekatan psikoanalisis, antropologis, dan sosiologis. Menurut Heilbroner, gagasan kapital sebagai suatu hubungan sosial menyingkapkan inti hubungan itu, yaitu dominasi. Hubungan dominasi memiliki dua kutub. Pertama, ketergantungan sosial kaum yang tak berpunya kepada pemilik kapital di mana tanpa 
Ekonomi Islam dan Kapitalisme...

ketergantungan itu kapital tidak memiliki pengaruh apa-apa. Kedua, dorongan tanpa henti dan tanpa puas untuk mengakumulasi kapital.

Heilbroner melontarkan pertanyaan: Apakah alasan pembenaran dari proses tanpa henti ini? Ia menyebutkan bahwa dorongan ini digerakkan oleh keinginan untuk prestise dan kemenonjolan (realisasi diri). ${ }^{14}$ Dalam bahasa Abraham Maslow, dorongan mengakumulasi kekayaan yang tidak puas-puas ini merupakan manifestasi aktualisasi diri. Namun, Heilbroner mengingatkan bahwa kebutuhan afektif ini hanyalah suatu kondisi yang perlu (necessary condition) namun belum menjadi syarat cukup (sufficient condition) untuk dorongan mengejar kekayaan. Lalu Heilbroner menemukan bahwa kekayaan memberikan pemiliknya kemampuan untuk mengarahkan dan memobilisasikan kegiatan-kegiatan masyarakat. Ini adalah kekuasaan. Kekayaan adalah suatu kategori sosial yang tidak terpisahkan dari kekuasaan.

Dengan demikian, hakekat kapitalisme menurut Heilbroner, adalah dorongan tiada henti dan tanpa puas untuk mengakumulasi kapital sebagai sublimasi dorongan bawah sadar manusia untuk merealisasi diri, mendominasi, berkuasa. Karena dorongan ini berakar pada jati diri manusia, maka kapitalisme lebih merupakan salah satu modus eksistensi manusia. Mungkin inilah sebabnya mengapa kapitalisme mampu bertahan dan malah menjadi hegemoni peradaban global.

\section{Benih Kapitalisme dalam Ekonomi Islam}

Luthfi Assyaukanie, pada kesempatan diskusi tentang "Islam dan Kapitalisme" yang diselenggarakan dalam rangka hari lahir Jaringan Islam Liberal ke-8, 23 dan 25 Maret 2009, mencoba mengurai perdebatan seputar hubungan antara Islam dan kapitalisme. Ia berupaya memberi bingkai kontekstual terhadap isu Islam dan kapitalisme. Menurut Luthfi, tema Islam dan kapitalisme sesungguhnya adalah rangkaian dari tema-tema umum yang mencoba mencari kompatibilitas antara Islam dan ideologi-ideologi lain seperti sosialisme, demokrasi, dan hak asasi manusia. Tentu saja ada banyak tantangan

\footnotetext{
${ }^{14}$ Heilbroner mengutip pernyataan Adam Smith sendiri dalam Theory of Moral Sentiments (1976): "Orang kaya berbangga dalam kekayaan-kekayaan mereka, karena dia merasa bahwa kekayaankekayaan itu membuatnya diperhatikan dunia. Memikirkan hal ini membuat dia berbesar hati dan membuatnya makin mencintai kekayaannya."
} 
dari dunia Islam untuk menerima konsep-konsep yang lahir di Barat tersebut. Itulah sebabnya, tidak sedikit orang, baik Islam maupun pengamat luar, yang menganggap bahwa Islam adalah sebuah masyarakat yang unik yang susah menerima konsep-konsep modern yang lahir dari Barat. Namun begitu, masih lebih banyak yang menganggap bahwa konsep-konsep yang sekarang berkembang di dunia modern adalah universal dan bukan merupakan produk unik dari budaya tertentu. Islam juga memiliki kompatibilitas dengan segala konsep yang bertujuan mengangkat harkat dan martabat manusia, darimana pun asalnya.

Menurut Luthfi, sikap antagonistik masyarakat Muslim terhadap kapitalisme disebabkan oleh beberapa hal. Pertama, pengalaman pahit masyarakat Muslim berhadapan dengan kolonialisme selama beberapa abad menjadikan masyarakat Muslim menolak apa saja yang datang dari negaranegara kolonial, terutama kapitalisme. Kolonialisme dianggap sebagai bentuk implementasi sistem ekonomi kapitalistik. Kedua, sikap materialistik yang ada dalam sistem kapitalisme dinilai berbahaya bagi iman Islam yang menekankan kehidupan setelah mati. Ketiga, kapitalisme dianggap melegalkan dan mendorong budaya hedonistik, sesuatu yang tidak patut dan tercela dalam kehidupan masyarakat Islam. Keempat, kapitalisme dianggap sebagai biang keladi kesenjangan dan kemunduran ekonomi masyarakat Muslim saat ini. Lebih dari itu, kapitalisme dianggap tidak memiliki kepekaan sosial. Luthfi menilai kesimpulan-kesimpulan ini terlalu sederhana dan cenderung menyesatkan.

Pengalaman kolonialisme tampaknya menjadi faktor utama sikap antagonistik ini. Luthfi mencontohkan bagaimana Tjokroaminoto menyebut ada dua macam kapitalisme: "kapitalisme baik" dan "kapitalisme buruk" (sinful capitalism). Kapitalisme yang baik adalah kapitalisme yang dijalankan oleh para pedagang dan pengusaha pribumi, terutama kaum Muslim. Sementara kapitalisme buruk adalah kapitalisme yang dijalankan oleh pengusahapengusaha Belanda dan antek-anteknya (terutama keturunan Cina). Sikap-sikap semacam ini tampak dominan di kalangan aktivis dan pemimpin bangsa Indonesia di awal-awal kebangkitan nasional dan kemerdekaan. Tidak heran kemudian jika yang muncul saat itu adalah sikap pro-sosialisme dan antikapitalisme. 
Ekonomi Islam dan Kapitalisme...

Senada dengan Luthfi, M. Dawam Rahardjo menilai bahwa memang ada kecenderungan masyarakat Muslim menolak sistem kapitalisme. Hampir semua wacana yang berkembang di dunia Islam awal abad ke-20 menempatkan Islam sebagai sesuatu yang tidak kompatibel bahkan anti-tesa terhadap kapitalisme. Islam didefinisikan justru dekat dengan sosialisme. Muhammad Iqbal, filsuf Islam asal Pakistan, bahkan menyebut Islam adalah varian dari sosialisme itu sendiri: "Islam is Bolshevism Plus God." HOS Tjokroaminoto menulis buku yang diberi judul "Sosialisme Islam." Mohammad Hatta dan M. Rasyidi menulis artikel di majalah Panji Masyarakat dengan judul "Islam dan Sosialisme.” Tokoh Masyumi, Sjafruddin Prawiranegara, mengeluarkan istilah "sosialisme religius."

\section{Islam Lahir pada Masyarakat Kapitalis}

Kedekatan Islam dan sosialisme yang dianut oleh banyak pengamat dibantah secara serius oleh Maxime Rodinson, Islam and Capitalism, yang menyatakan bahwa sesungguhnya dunia Islam justru sangat dekat dengan kapitalisme. Rodinson meminjam kerangka teori sosiologi Max Weber yang menemukan bahwa sangat mungkin aspek-aspek kesadaran religius Protestantisme berpengaruh terhadap perkembangan dan kemunculan kapitalisme. Kendati pada tahap selanjutnya kapitalisme menjadi sangat berpengaruh terhadap perkembangan agama itu sendiri.

Menurut Rodinson, kapitalisme harus dibedakan dalam dua kategori: kapitalisme sebagai institusi dan kapitalisme sebagai mentalitas. Dari kedua kategori ini, kapitalisme muncul dalam tiga bentuk: kapitalisme komersial, kapitalisme finansial, dan kapitalisme industrial. Masyarakat Muslim, menurut Rodinson, datang pada konteks masyarakat Arab yang mempraktikkan kapitalisme komersial. Tidak heran kemudian jika bahasa perdagangan akan sangat mudah ditemui dalam al-Qur'an, misalnya "Hal adullukum 'alā tijärab" (Maukah engkau kuberi tahu tentang perdagangan?) (QS. al-Shaff [61]:10).

Dalam sejarah Islam awal, Kapitalisme Awal, yang disebut juga sebagai Kapitalisme Komersial, sudah hadir di Mekah. Elite Mekah adalah sebuah kelas pedagang yang memerintah dalam sistem plutokrasi. Dalam pembahasan Rodinson, suku Quraisy adalah suku yang memiliki privilege dan atas dasar itu mereka mengakses kekuasaan Di Mekah, Islam lahir dalam konteks masyarakat 
kapitalis komersial semacam itu. Dalam Kapitalisme Komersial semacam itu terjadi juga transaksi-transaksi finansial yang berpusat di Mekah yang berbasis riba. Namun Islam datang mengoreksi sistem riba dengan sistem zakat yang berdimensi sosial.

Karena itu, Islam sulit dipisahkan dengan sistem kapitalisme. Meski Islam melahirkan koreksi-koreksi etis tertentu, norma-norma Islam sebagai agama sejalan dan tidak menghambat perkembangan ekonomi. Dengan terbentuknya negara kekhalifahan, negara ikut serta mengintervensi ekonomi, misalnya dengan penarikan zakat dan pajak, pembentukan griya arta (bait al$m a \bar{l})$ untuk kepentingan sosial serta menyediaan dana untuk melancarkan perdagangan.

Ini tentu berbeda dengan sikap gereja Katolik di Abad Pertengahan Eropa yang menilai perdagangan sebagai pekerjaan yang tidak patut dilakukan oleh kaum Kristiani. Pedagang disamakan atau disejajarkan dengan pencuri. Sebagaimana dipercaya dalam mitologi Yunani Kuno, dewa kaum pedagang yeng bernama Hermes, juga dewa kaum pencuri. Ajaran gereja memusuhi usaha-usaha mencari kekayaan material karena dianggap sebagai pemujaan terhadap Dewa Mammon.

Ajaran-ajaran seperti itu tidak ada pada Dunia Islam Abad Pertengahan. Bahkan pada awal perkembangannya, Islam dipeluk oleh anak-anak muda kelas pedagang. Nabi sendiri dan istrinya adalah pedagang. Sahabat-sahabat Nabi paling awal, kemudian menjadi pedagang kaya. Menantu Nabi, Usman bin Affan, adalah seorang pedagang yang kaya raya dan mendermakan kekayaannya untuk perkembangan Islam. Itulah penjelasan dari pandangan Rodinson bahwa ajaran Islam tidak memusuhi dan merusak Kapitalisme Komersial. Bahkan Islam menyuntikkan etos ekonomi pada masyarakat Madinah.

Dawam menilai bahwa meski Islam lahir dalam konteks kapitalisme, tetapi hubungannya bukan hubungan statis. Di samping menerima konsep kapitalisme, Islam juga memberi kritik dan masukan. Islam memperkenalkan dua modal ekonomi, yaitu finasial dan manusia: "Wajāhidū bi amwālikum wa anfusikum fi sabililläbi" (Berjihadlah di jalan Allah dengan harta dan jiwamu) (QS. al-Taubah [9]:41). Menurut Dawam, hal ini sejalan dengan kapitalisme, 
sebagaimana yang diterangkan dalam teori pertumbuhan Harold-Domar, bahwa ada dua modal dalam ekonomi: modal finansial atau fisik dan modal tenaga kerja manusia.

Islam, dalam kacamata Rodinson, berkembang dari masyarakat kapitalisme tradisional. Sejarah kemudian mencatat bahwa Islam tersebar ke pelbagai pelosok dunia juga dengan menggunakan kendaraan kapitalisme dan perdagangan. Itulah sebabnya penyebaran Islam lebih lambat 300 tahun dari perluasan kekuasaan politik raja-raja Islam. Ini pula yang dijadikan sebagai argumen untuk membantah tesis yang menyatakan bahwa Islam disebarkan dengan pedang dan darah.

Sejak awal, kapitalisme dan Islam sudah berada pada jalur yang sama. Dawam menegaskan bahwa apa yang disebut sebagai etika ekonomi Islam sesungguhnya berjalan sejajar dengan norma ekonomi kapitalisme. Fakta bahwa etika mengenai kerja, kekayaan dan kepemilikan, perdagangan, keuangan, industri, dan pelbagai inovasi teknologi yang berkembang pesat pada masa-masa kejayaan Islam membuktikan bahwa norma kapitalisme tumbuh subur dalam budaya ekonomi Islam. Rodinson bahkan menyebut kota-kota semacam Granada, Cordoba, Baghdad, Damaskus dan kota-kota besar Islam lainnya adalah sama dengan Paris, London, atau Washington pada masanya. Mereka adalah kota-kota metropolitan dan pusat-pusat kapitalisme dunia.

Namun begitu, Dawam membatasi kompatibilitas Islam dan kapitalisme hanya pada kapitalisme tradisional atau kapitalisme komersial. Sementara kapitalisme dalam bentuk yang lebih mutakhir seperti kapitalisme negara (state capitalism), kapitalisme finansial, maupun kapitalisme monopoli memerlukan penjelasan yang lebih hati-hati. Bicara mengenai kompatibilitas Islam dan kapitalisme sesungguhnya memiliki persoalan serius, sebab keduanya memiliki varian yang sangat kaya. Islam dan kapitalisme mana yang kita maksud?

Bagi Dawam, kapitalisme dalam beragam bentuk adalah sebuah kemestian. Tidak ada negara dan masyarakat yang benar-benar bisa lepas dari sistem ini, mulai dari tahap tradisional (komersial), politik, maupun rasional (meminjam kategori Max Weber). Apa yang runtuh di Uni Soviet dan Cina 
sekarang ini bukanlah sistem ekonomi sosialisme, melainkan kapitalisme negara (state capitalism). Sosialisme sesungguhnya tidak pernah runtuh, karena munculpun belum. Pada akhirnya, kapitalisme menjadi semacam sunnatullah dengan berbagai varian dan perkembangannya.

\section{Etos Dagang Kaum Santri}

Di langgar Kidul, Kauman, Yogyakarta, 100 tahun silam, KH. Ahmad Dahlan bersila takzim. Belasan santri duduk melingkar menghadap sang kiai. Malam itu, seperti juga pada pengajian sebelumnya. Kiai Dahlan lagi-lagi mengajarkan surah al-Ma'un, yang antara lain berisi perintah menyantuni yatim piatu dan fakir miskin. Merasa bosan dengan pelajaran yang itu-itu saja, seorang santri memberanikan diri bertanya, "Kiai, kenapa tidak ada penambahan pelajaran?" Yang ditanya malah balik bertanya, "Apakah kamu sudah mengerti betul?" Dengan suara mantap, sang santri menjawab, "Kita sudah hafal semua, Kiai."

Dan Kiai Dahlan pun balik bertanya, "Kalau sudah hafal, apakah sudah kamu amalkan?" Santri itu berucap, "Bukankah surah al-Ma'un berungkali kami baca untuk rangkaian al-Fatihah di kala salat." Jawaban si santri tidak memuaskan sang kiai. "Bukan itu yang saya maksud. Diamalkan artinya dipraktikkan, dikerjakan," Kiai Dahlan menegaskan. Saat itu pula Kiai Dahlan memerintahkan santrinya berkeliling kampung mencari orang miskin. Kalau sudah ketemu, harus dibawa ke rumah masing-masing. "Berilah dia sabun yang baik untuk mandi! Berilah pakaian yang bersih. Berilah makanan dan minuman serta tempat tidur!" perintah Dahlan. Titah Kiai Dahlan tersebut mengisyaratkan bahwa Islam bukan hanya ritual ibadah saja. Tapi Islam adalah bekerja, agar bermanfaat bagi diri sendiri dan orang lain.

Jika Kristen punya etika protestan yang menjadi spirit kapitalisme di Eropa barat sebagaimana yang diketemukan Max Weber dalam The Protestant Ethics And The Spirit of Capitalism (1937), maka Islam juga punya etos bisnis yang bahkan menurut Perter L Bernstein, mengungguli etos bisnis bangsa mana pun di dunia ini. ${ }^{15}$

15 Bernstein, Peter L., The Power of Gold-The History of Obsession, New York: John Wiley and Sons Inc, 2000 . 
Ekonomi Islam dan Kapitalisme...

By nature dan by teaching, Islam sangat mendorong entrepreneurship. Islam adalah agama kaum pedagang. Lahir di kota dagang, dan disebarkan ke nusantara oleh kaum pedagang. Nabi Muhammad saw dan sebagian besar sahabatnya adalah para pedagang dan entrepreneur mancanegara. Tidak berlebihan karenanya bila dikatakan bahwa etos entrepreneurship sudah melekat dan inheren dengan diri umat Islam. Islam mengangkat derajat kaum pedagang sehingga profesi ini yang pertama mendapat kehormatan untuk membayar zakat.

Sejarah penyebaran Islam ke berbagai penjuru dunia, sampai abad ke-13 M dilakukan oleh para pedagang muslim. Hal ini menjadi bukti lain bahwa etos bisnis (dagang) kaum muslim sangat tinggi, yang menyeruak hingga mancanegara. Termasuk keberadaan Islam di Indonesia. Adalah para pedagang yang membawa dan menyebarluaskannya. Selain ilmu agama, mereka juga mewariskan keahlian berdagang ke masyarakat, khususnya di kalangan masyarakat pesisir.

Dalam Peddlers and Princes (1963), Clifford Greetz menyatakan bahwa di kalangan pribumi kepeloporan di bidang perdagangan berada di tangan para santri. Pedagang dan pengusaha di Mojokuto, selain orang Cina, pastilah santri reformis. Di luar perusahaan-perusahaan yang dimiliki Cina, semuanya adalah milik orang Islam reformis atau yang terpengaruh oleh gagasan reformisme Islam. Pada bagian lain dari penelitiannya pada 1950-an itu, Greetz menjelaskan bahwa reformisme dan puritanisme Islam merupakan doktrin bagi hampir semua pengusaha dan entrepreneur di sana. Watak kehidupan puritan yang asketik ini mengajarkan kesalehan yang paling tinggi ialah selain iman itu sendiri, seseorang yang sudah beriman harus banyak beramal saleh. Sebuah dorongan yang dalam istilah Weberian disebut religious calling. ${ }^{16}$

Kuntowijoyo dalam penelitiannya mengenai para pengusaha kerajinan besi di Batur, Klaten, juga melihat adanya hubungan yang erat antara kehidupan keagamaan para santri dan perilaku kewirausahaan mereka. Puritanisme Islam, di samping menganut sikap hidup asketisme, juga memiliki doktrin mewajibkan para pengikutnya untuk lebih bersemangat dan

\footnotetext{
16 Peddlers and Princes, 1963.
} 
bersungguh-sungguh dalam usaha ekonomi. Bekerja dianggap sebagai makna yang sebenarnya dari al-Qur'an dan hadis.

Tidak hanya itu, semangat kapitalisme sempat menjadikan penyokong bagi kongsi-kongsi Islam dari orang-orang Melayu di Aceh, dari orang-orang Palembang, dan juga etnis Bugis di Sulawesi. Organisasi pergerakan Sarekat Dagang Islam, adalah salah satu bukti bahwa semangat kapitalisme umat Islam ikut mendorong terjadinya perubahan ekonomi, social, dan politik bangsa ini.

Sementara itu organisasi massa Islam yang sampai sekarang masih eksis seperti Muhammadiyah tidak lain sesungguhnya didirikan oleh para saudagar santri dan para pedagang di kota-kota. Sejarah Muhammadiyah tidak bisa dipisahkan begitu saja dengan bangkitnya kekuatan ekonomi para saudagar, seperti pengusaha tekstil atau tenun di Pekajangan, Pekalongan, dan yang ada di daerah Laweyan, Surakarta.

Demikian pula Nahdlatul Ulama (NU), yang sejatinya didahului dengan gerakan organisasi Nabdlatut Tujjar (Kebangkitan Kaum Pedagang). Menurut peneliti NU, Martin van Bruinessen, orientasi bisnis NU itu juga dipengaruhi oleh visi Sarikat Islam (SI). Wahab Chasbullah penggerak penting NU, pernah terlibat di SI sejak masih belajar di Mekkah. Komposisi pengurus NU periode pertama merupakan kolaborasi ulama (di Syuriah) dan pengusaha (di Tanfidziyah).

\section{Kapital dan Prinsip Kepemilikan dalam Islam}

Guna memahami ajaran Islam tentang harta milik pribadi, perlu dilihat prinsip umum ekonomi Islam: (1) Tuhan menciptakan dunia dengan kekayaan yang melimpah bagi manusia untuk dinikmati dan dimanfaatkan; (2) Karenanya, semua itu menjadi milik mereka kalau mereka mau berusaha dan tidak melakukan ketidakadilan dan kejahatan; (3) Namun, mereka harus memerhatikan kebutuhan jangka pendek dan panjang masyarakat luas. ${ }^{17}$

Dalam hal ini ada dua karakteristik ekonomi Islam yang harus dipahami, yaitu: (1) semua harta, baik benda maupun alat produksi adalah milik (kepunyaan) Allah. Hal itu bermakna bahwa, pemilik harta yang sesungguhnya adalah Allah swt sementara manusia hanya memiliki hak untuk men-tasharruf-

17 Hossein Askari, 1985, hlm. 52 
Ekonomi Islam dan Kapitalisme...

kan (memanfaatkan) harta itu. (2) Manusia adalah khalifah atas harta miliknya. Sebagai khalifah atas harta miliknya, maka manusia diberi hak untuk memanfaatkannya, sebatas sebagai wakil-wakil Allah dalam penggunaan harta tersebut. $^{18}$

Islam betul-betul mengakui penghakan atas harta milik secara pribadi. ${ }^{19}$ Namun pemilikan pribadi berbeda dengan pemilikan absolut, hanya Tuhan yang berhak untuk hal ini. Pemilikan pribadi yang sah adalah hak untuk memanfaatkannya dan membagi-bagikannya.

Secara umum, Nabi Muhammad tidak pernah mengecam praktik pengumpulan kekayaan. Yang dikecam adalah praktik kecurangan dalam kegiatan ekonomi tersebut. Beberapa literatur bahkan menempatkan Nabi sebagai pembela mekanisme pasar. Dia, misalnya, menolak permintaan para sahabat untuk mengendalikan gejolak ekonomi dengan mematok harga. Mematok harga adalah perbuatan yang melawan sunnatullah. "Sesungguhnya Allahlah yang menetapkan harga, dan menurunkannya, melapangkan dan meluaskan rezki. Janganlah seseorang di antara kalian menuntut saya untuk berlaku zalim dalam soal harta maupun nyawa" (HR. Bukhari, Muslim, Abu Dawud, Tirmidzi, Ibnu Majah, Ahmad, dan Ibnu Hibban).

Ekonomi pasar kemudian menjadi kemestian dalam sistem ini. Islam, adalah seperangkat nilai yang dijadikan jalan hidup yang digali dari kitab suci dan turunan penafsirannya. Al-Qur'an secara spesifik tidak bicara tentang sistem ekonomi tertentu. Tetapi ada banyak ayat yang mengindikasikan pembicaraan mengenai ekonomi: transaksi jual beli (QS. al-Baqarah [2]:282), kontrak hutang (QS. al-Baqarah [2]:282), bunga (QS. al-Baqarah [2]:275), pinjaman (QS. al-Baqarah [2]:282), dan pajak (QS. al-Taubah [9]:103). Prinsip property right yang menjadi dasar kapitalisme tampak nyata dalam fakta bahwa al-Qur'an tidak pernah melarang kaum Muslim untuk memiliki harta. Kaum Muslim justru dianjurkan untuk giat berusaha mengumpulkan harta (QS. alJumu'ah [62]:10 dan al-Muzzammil [73]:20). Orang yang mati membela harta milik atau sedang dalam usaha mengumpulkan harta untuk keluarga bahkan disebut sebagai martir (syahid).

18 Ali Yafie, dkk, Fiqh Perdagangan Bebas, Jakarta: Teraju, 2003, hlm. 30

19 Abu Sulayman, t.t., hlm. 480 
Sistem ekonomi Islam memiliki pandangan bahwa seluruh harta yang ada di dunia ini sesungguhnya milik Allah, berdasarkan firman Allah, "dan berikanlah kepada mereka sebagian dari harta Allah yang dikaruniakannya kepadamu" (QS. al-Nur [24]:33)

Dari ayat tersebut dapat dipahami bahwa harta yang diberikan Allah kepada manusia adalah merupakan pemberian dari Allah yang dikuasakan kepadanya. Penguasaan ini berlaku umum bagi semua manusia. Semua manusia mempunyai hak kepemilikan, tetapi bukan kepemilikan yang sebenarnya.

Oleh sebab itu, menurut Islam harta itu seharusnya hanya bisa dimiliki, dimanfaatkan, dikembangkan, dan didistribusikan secara sah sasuai dengan yang di perintahkan oleh Allah. Dan dapat disimpulkan bahwa sistem ekonomi Islam dapat dicakup dalam tiga buah yang utama, yaitu:

1. Kepemilikan (al-milkiyah)

2. Pemanfaatan dan pengembangan kepemilikan (al-tasharruf al-milkiyyah)

3. Distribusi harta kekayaan di tengah-tengah manusia (tauri" tsarwah bayna al$n \overline{a s})$

Mekanisme pasar bebas yang dianjurkan dalam kapitalisme, ternyata jauh sebelumnya Rasulullah saw telah menyetujui market mechanism of price dan menganjurkan kepada umatnya untuk memanfaatkan mekanisme pasar dalam penyelesaian masalah-masalah ekonomi dan menghindari tasitr (penetapan harga oleh pemerintah) jika tidak diperlukan. Namun, bukan berarti penetapan harga selamanya dilarang, melainkan dianjurkan untuk barang-barang publik (public goods) dan kondisi khusus lainnya seperti dijabarkan oleh Ibn Taimiyyah dalam bukunya, Aḥkām al-Sūq. ${ }^{20}$ Pertentangan utama kapitalisme dengan ekonomi Islam adalah terletak pada asas individu yang dianutnya. Di mana kapitalisme sangat menjunjung tinggi kebebasan berusaha dengan semangat kompetisi antar individu tanpa sama sekali mempermasalahkan penumpukan harta kekayaan, pengembangannya secara riba dan akumulasi kapital, serta masalah pembelanjaannya yang menanggalkan nilai-nilai sosial. Asas yang lebih tepat disebut homo-homini lupus (manusia adalah serigala bagi manusia lainnya).

\footnotetext{
20 Adiwarman A. Karim, Ekonomi Islam Suatu Kajian Kontemporer, Jakarta: Gema Insani Press, 2001.
}

Volume VII/Edisi 1/Mei 2016 
Ekonomi Islam dan Kapitalisme...

Perhatian terhadap kepentingan orang lain hanya dilaksanakan dengan pertimbangan penambahan manfaat (marginal profit and utility) yang dapat dijelaskan dengan konsep pareto optimum improvement.

\section{Kesimpulan}

Islam dan kapitalis, dua hal yang saling memengaruhi. Secara sosiologis, Islam hadir pada masyarakat kapitalis. Tak heran jika keduanya memiliki satu keterikatan. Kapitalisme, khususnya Kapitalisme Perdagangan (Commercial Capitalism) sudah ada sebelum Islam datang. Sebelum Islam lahir, Mekah sudah merupakan pusat perdagangan dan keuangan internasional yang maju. Nabi Muhammad sendiri adalah seorang pedagang sebelum diangkat menjadi nabi.

Dengan demikian, kapitalisme adalah suatu paham atau sistem yang datang dari luar dan malah merupakan satu aliran pemikiran ekonomi yang masuk dan ikut memengaruhi ekonomi Islam. Tentu saja, dalam perkembangannya, ajaran Islam ikut memengaruhi dan mengoreksi kehidupan ekonomi atau kapitalisme yang berlaku. Karena itu Islam dan kapitalisme adalah dua kekuatan yang saling berinteraksi dan memberi pengaruh. 


\section{DAFTAR PUSTAKA}

Bernstein, Peter L., The Power of Gold-The History of Obsession, New York: John Wiley and Sons Inc, 2000.

Depag RI, Al-Qur'an dan Terjemahnya, 1983/1984.

Dillard, Dudley, Kapitalisme Dulu dan Sekarang, terj. oleh M. Dawam Rahardjo, Jakarta: LP3ES, 1987.

Ebenstein, W., Isme-Isme Dewasa Ini, (terj), Jakarta: Erlangga, 1980.

Karim, Adiwarman A., Ekonomi Islam Suatu Kajian Kontemporer, Jakarta: Gema Insani Press, 2001.

Kunio, Yoshihara, Kapitalisme Semu Asia Tenggara, Jakarta: LP3ES, 1990.

Lerner, Robert. E., Western Civilization, Volume 2, W.W. Norton \& Company, Ney York-London: 1988.

Rand, A., Capitalism: The Unknown Ideal, A Signet Book, New York: 1970.

Tawney, RH., Religion and The Rise of Capitalism, 1922.

Turner, Jonathan H., The Emergence of Sociological Theory, Illinois: The Dorsey Press, 1981.

Yafie, Ali, dkk, Fiqh Perdagangan Bebas, Jakarta: Teraju, 2003. 